\title{
Assessment of the quality of quaternary groundwater under the influence of anthropogenic activities in the low-income neighbourhoods of the Treichville municipality (Abidjan, Côte d'Ivoire)
}

\author{
David Konan Kouassi ${ }^{1}$ - Innocent Kouassi Kouame ${ }^{1}$ - Kouadio Koffi ${ }^{1} \cdot$ Aristide Gountôh Douagui ${ }^{1}$. \\ Andrei Victor Sandu ${ }^{2,3} \cdot$ Ion Sandu ${ }^{4}$
}

Received: 1 June 2020 / Accepted: 1 September 2020 / Published online: 22 September 2020

C) Springer Nature Switzerland AG 2020

\begin{abstract}
This study aims to assess the groundwater quality and the origin of water mineralization in an environment with high anthropogenic pressure in the municipality of Treichville. Twenty-one water samples were analysed to determine the quality. Kruskal-Wallis nonparametric test, Mann-Whitney test, Kohonen algorithm, and water table building were used to determine the factors influencing the mineralization. The results showed that the well's water contains chemical and bacteriological elements whose concentrations are higher than the standards authorized by the World Health Organization (WHO). Thus, high levels of nitrate (peak $=173.1 \mathrm{mg} \mathrm{L}^{-1}$ ), phosphate (peak $=1.03 \mathrm{mg} \mathrm{L}^{-1}$ ), lead (peak $=2.987 \mathrm{mg} \mathrm{L}^{-1}$ ), and Escherichia coli (peak $=2.31 \times 10^{5}$ UFC $100 \mathrm{~mL}^{-1}$ ) were obtained in these waters. So, the groundwater is not suitable for human consumption. The most mineralized waters are found in the areas near the Ebrie Lagoon and extend in the direction including the low-income neighbourhoods of Biafra, Nanan Yamousso and Appolo. Pollutant transfer is continuous in the study area and comes from surface sewage, latrines, sewage disposal systems, well water collection materials, and the Ebrié Lagoon. Indeed, the pollutants leave Biafra neighbourhoods where water is heavily polluted and the pollution is amplified by the presence of septic tanks and latrines located on the line of groundwater flow. The main factors influencing water quality are the lagoon water intrusion, the advection mechanism linked to the infiltration of surface water and the lateral migration of pollutants from septic tanks and latrines, and mechanism of dissolution of the clay component of the clayey-sandy layers.
\end{abstract}

Keywords Groundwater · Quality · Mineralization · Anthropogenic activities · Low-income neighbourhoods

\section{Introduction}

Groundwater is a vital resource for humans [58]. However, the quality of this water is increasingly deteriorating due to the evolution of anthropogenic activities in the rural and urban environment $[32,39,57]$, leading to major health risks for the population and particularly for low-income populations. According to $\mathrm{WHO}$ [56], about $80 \%$ of all human diseases are caused by water. Indeed, the occurrence of waterborne diseases such as cholera, diarrhoea, typhoid fever, and gastrointestinal infections is often linked to the consumption of contaminated groundwater [23]. Thus, a large number of incidents of physical, chemical, and microbiological groundwater pollution have

$\triangle$ Innocent Kouassi Kouame, innocent_kouassi@yahoo.fr; Andrei Victor Sandu, sav@tuiasi.ro; euroinvent@yahoo.com; lon Sandu, ion.sandu@uaic.ro| ${ }^{1}$ Laboratory of Geosciences and Environment (LGE), UFR Sciences and Environmental Management, University Nangui Abrogoua, 02 BP 801, Abidjan 02, Côte d'Ivoire. ${ }^{2}$ Faculty of Materials Science and Engineering, Gheorghe Asachi Technical University of lasi, Blvd. D. Mangeron 71, 700050 lasi, Romania. ${ }^{3}$ School of Material Engineering, Center of Excellence Geopolymer and Green Technology (CeGeoGTech), Universiti Malaysia Perlis (UniMAP), P. O. Box 77, d/a Pejabat Pos Besar, 01000 Perlis, Kangar, Malaysia. ${ }^{4}$ Department of Science, Arheoinvest Centre, Institute of Interdisciplinary Research, Alexandru loan Cuza University, 11 Carol I Blvd, 700506 lasi, Romania. 
been reported worldwide by several authors $[7,10,38-40$, 49, 59].

Many urban communities in Africa depend on well water as their main source of drinking water or for other domestic uses. Indeed, much urban growth occurs in or around already overcrowded urban shantytowns, periurban areas and informal settlements [24]. Thus, in these low-income neighbourhoods, groundwater contamination is attributed to surface water percolation, septic tanks, cesspools, and latrines using animal manure stored in landfills or applied to agricultural land as fertilizer [15, 30, $33,34,42,53]$.

In Côte d'Ivoire, particularly in the south of Abidjan metropolis, studies have been carried out on the general quality of the quaternary groundwater. Among these researches, those of Yapo et al. [60] showed high concentrations of nitrate (maximum: $286 \mathrm{~m} \mathrm{~L}^{-1}$ ), ammonium (maximum: $73.7 \mathrm{mg} \mathrm{L}^{-1}$ ), sulphate (maximum: $150 \mathrm{~m} \mathrm{~L}^{-1}$ ), and chloride (maximum: $192 \mathrm{~m} \mathrm{~L}^{-1}$ ) in the well water in this part of the metropolis. In addition to these ions, they detected the presence of intestinal enterococci, thermotolerant coliforms, total coliforms, and sulphite-reducing clostridial spores. They concluded that these pollutions would be from latrines, cesspits, septic tanks, wild garbage dumps, and groundwater quality varies from one municipality to another, and pollution sources are punctual, even within each zone. However, some low-income households still depend on them for their drinks and household activities. Therefore, the precarious environmental conditions of these vulnerable populations require specific studies for the development of strategies within the context of environmental management and population protection programmes.

Treichville is one of the municipalities in the southern part of the Abidjan metropolis. In this municipality, many low-income households use well water. However, the domestic effluent disposal system is not very developed and is inefficient. The rate of house connections to the collective sewerage network is $1.89 \%$ [13] and causes wastewater flows in certain houses and alleys. Latrines and septic tanks used as a means of excreta disposal are sometimes located near wells. Also, a large part of the Treichville municipality is bordered by the Ebrié Lagoon which receives wastewater without any treatment or not sufficiently treated [25]. The proximity of wells and latrines, as well as the possibility of communication of the lagoon with the quaternary groundwater, would expose the population to high health risks. According to the annual reports of the Ministry of Health and Public Hygiene on the health situation [43-45], diarrhoea and typhoid fever are still present in the sanitary district of Treichville-Marcory with rates varying between 13.2 and $100.7 \%$ and between 97.94 and $112.29 \%$, respectively. These cases have been observed in adults as well as in children under 5 years of age. For Su et al. [54], the quality of groundwater may be closely linked to human health. The pollution generated by anthropogenic activities can, when reaching critical levels, present a danger to public health [5]. So far, the studies carried out are descriptive and have not yet succeeded in establishing a direct link between the quality of well water, the main factors that influence this quality, and the hydrodynamic behaviour of the aquifer. The goal of this study is to determine the relationship between the seasonal distribution of the main pollutants in well waters in the municipality of Treichville and the evolution of the groundwater table. Specific objectives are to (1) determine the chemical and bacteriological quality of well water, (2) determine factors influencing groundwater mineralization, and (3) determine the relationship between groundwater table and the spatial and temporal distribution of main pollutants in the groundwater.

\section{Materials and methods}

\subsection{Study site description}

The municipality of Treichville is located in the south of the Abidjan metropolis, with a total area of $8.9 \mathrm{~km}^{2}$ and an estimated population of about 102580 inhabitants [50]. It is bounded to the north, west, and south by the Ebrié Lagoon and to the East by the municipality of Marcory (Fig. 1). The municipality comprises several lowincome households located in Biafra, in Appolo, in Nanan Yamousso, and in "Notre Dame" parish area. The climate is of a sub-equatorial transitional type characteristic of that of the District of Abidjan. Thus, the period from May to June corresponds to the long rainy season (LRS) and the period from October to November corresponds to the short rainy season (SRS). The periods from December to April and from July to September correspond to, respectively, the period of the long dry season (LDS) and the short dry season (SDS). The study area is located in the south of the Ivorian coastal sedimentary basin where the quaternary outcrops. Several sedimentary units can be identified. The clayey sands of the lowlands are presented in massive bands and form flat surfaces located between 10 and $12 \mathrm{~m}$ above sea level. The aquifer includes two aquifers: the Oogolian and the Nouakchottan aquifers. But the Oogolian groundwater located in the north half is the one that is captured by the majority of wells in the municipality of Treichville [41]. The piezometric levels vary between 3.36 and $9.70 \mathrm{~m}$ during the rainy season and $3.27 \mathrm{~m}$ and $9.65 \mathrm{~m}$ during the dry season. The permeability of the shallow aquifer in which this groundwater develops 
Fig. 1 Presentation of Treichville municipality
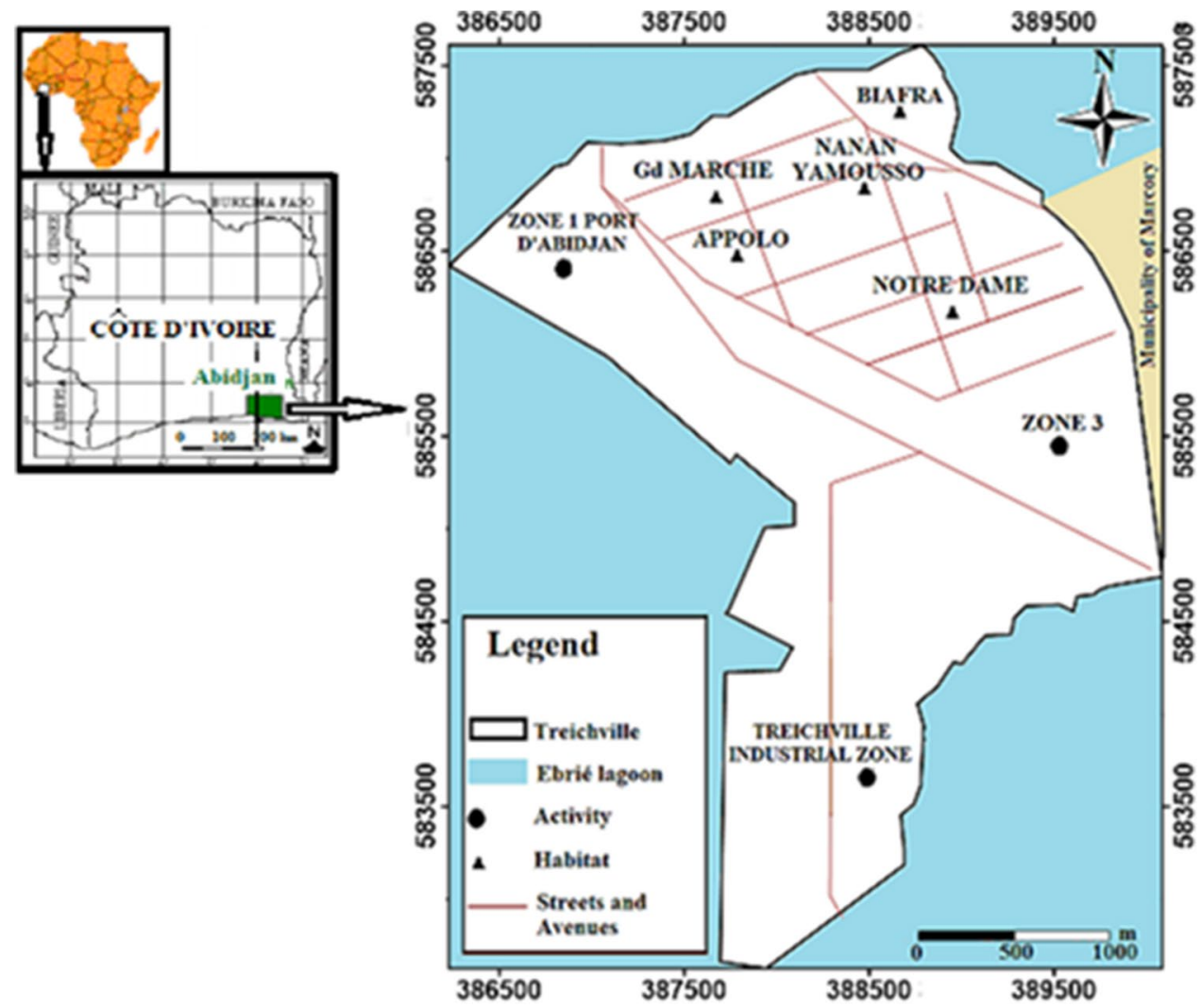

ranges from $10^{-4}$ to $10^{-3} \mathrm{~m} \mathrm{~s}^{-1}$ for clayey sands and $10^{-3}$ $\mathrm{m} \mathrm{s}^{-1}$ for marine cordon sands [26].

\subsection{Sampling and measured parameters}

Water samples from twenty-one wells were collected in June (LRS), August (SDS), September (SRS), and January (LDS). The sampling covered 21 wells whose water is used for domestic purposes (drinking, cooking, ablution, bathing, tooth brushing) of the populations. The choice of these wells was based on the proximity of the wells to the sources of pollution while taking into account the spatial distribution of the wells. The wells (sampling sites) are labelled P1 to P21 (Fig. 2). Two polyethylene bottles with a capacity of $1 \mathrm{~L}$ and one glass bottle with a capacity of $1 \mathrm{~L}$ were used for each sampling. The sample in the glass bottle, intended for the analysis of heavy metals (lead $(\mathrm{Pb})$, cadmium $(\mathrm{Cd})$, was filtered and then acidified with $2 \mathrm{ml}$ of concentrated nitric acid. Concerning the other two samples, one is for anions and cations analysis and the other for bacteriological germs detection. These two samples were not filtered or acidified. Physical parameters, particularly temperature $(T)$, electrical conductivity (EC), and salinity, were measured in situ with a multiparameter HANNA 9828. The sterilized bottles were washed three times with the water to be sampled before sampling. The samples collected were labelled and transported to the

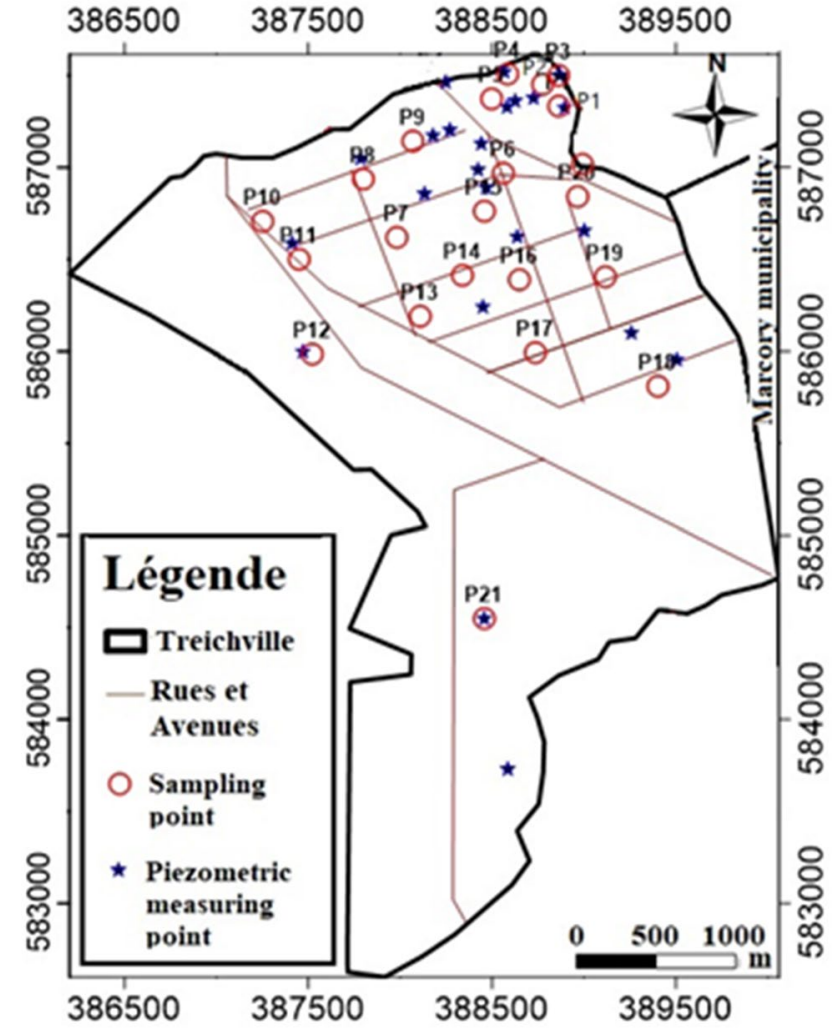

Fig. 2 Location of water sampling points and water levels measurements 
laboratory in an icebox at $4{ }^{\circ} \mathrm{C}$. The analyses were carried out in the $12 \mathrm{~h}$ following the sampling. Nitrite ions $\left(\mathrm{NO}_{2}{ }^{-}\right)$, ammonium ions $\left(\mathrm{NH}_{4}{ }^{+}\right)$, sulphate ions $\left(\mathrm{SO}_{4}{ }^{2-}\right)$, phosphate ions $\left(\mathrm{PO}_{4}{ }^{3-}\right)$, nitrate ions $\left(\mathrm{NO}_{3}{ }^{-}\right)$were quantified by molecular absorption spectrometry JASCOV-530 with a precision of $0.5 \mathrm{~nm}$. Sodium $\left(\mathrm{Ca}^{2+}\right)$, magnesium $\left(\mathrm{Mg}^{2+}\right)$, sodium $\left(\mathrm{Na}^{+}\right)$, and potassium $\left(\mathrm{K}^{+}\right)$ions were quantified by atomic absorption spectrometry Varian AA 20 with a precision of $0.5 \mathrm{~nm}$. Total coliforms (TC), Escherichia coli (E. coli), Clostridium perfringens (CP), Faecal Streptococcus (FS), and $C$. perfringens $(\mathrm{CP})$ were quantified by the solid media counting method according to NF ISO 16649-2 standard. A piezometric campaign was associated with water sampling using a HERON Dipper-T probe. These measures were carried out in 25 wells.

\subsection{Statistical analyses}

\subsubsection{Chemical and bacteriological parameters assessment}

The Kruskal-Wallis nonparametric test was used to assess the variability of some pollution indicator parameters (nitrate, lead, sulphate, and Escherichia coli) over the different seasons and between sampling points. The significance of the results is evaluated using the probability value " $p$ ". When $p$ is greater than 0.05 , there is no significant variation in the parameter studied. Otherwise $(p<0.05)$, a significant difference is deduced. The Mann-Whitney test is applied to determine this difference. The choice of the nonparametric Kruskal-Wallis test is supported by the distribution of data previously evaluated using the Shapiro-Wilkinson normality tests (sample size $<50$ ). When the data do not follow the normal law, the corresponding test is the nonparametric Kruskal-Wallis test.

The tests were carried out with $\mathrm{R}$ software version 3.6, with the package «vegan ».

\subsubsection{Characterization of groundwater mineralization processes}

The different processes involved in water mineralization were determined from the correlations obtained between electrical conductivity and physicochemical and bacteriological parameters. These correlations were determined using the self-organizing maps (SOM) algorithm. The SOM algorithm principle is to carry out a nonlinear classification of complex databases by identifying similar groups. Thus, from an unsupervised learning process, this algorithm iteratively searches for similarities among the observed data. It represents these similarities on an output map (or Kohonen map) by preserving neighbourhoods [14]. The learning is done with different card sizes. Optimal size is chosen by minimizing quantification (EQ) and topographical errors $[35,48]$. The architecture of the SOM algorithm is composed of an input layer and an output layer. In this study, the input layer is composed of 22 neurons represented by the 22 physicochemical and bacteriological parameters. These neurons are connected to each of the 84 samples or vectors ( 21 water samples collected per season, or $21 \times 4$ ) in the database. The twodimensional output layer is composed of 25 neurons ( 5 rows $\times 5$ columns). The binding coefficients were computed between variables by using the Spearman correlation test. STATISTICA 7.0 software was used for the statistical tests.

\section{Results and discussion}

\subsection{Seasonal distribution of chemical and bacteriological quality of well water}

Table 1 statistically summarizes the groundwater quality in the studied area by minimum, maximum, and average values for the long rainy season (LRS), short dry season (SDS), short rainy season (SRS), and long dry season (LDS) along with the WHO guideline values [56].

It is observed that the temperature is ranged between 25.79 and $30.49 \mathrm{mg} \mathrm{L}^{-1}$ globally of all the seasons. The temperature values obtained during the four seasons are higher than WHO's guideline value for drinking water quality. However, these temperatures are similar to the temperatures of Greater Abidjan ( 25.5 to $30.4^{\circ} \mathrm{C}$ ) obtained by several authors $[3,14,60]$ in the study area and authors who have worked on groundwater quality in sub-Saharan Africa [6, 30, 31, 37]. These temperatures, which correspond to seasonal variations in ambient atmospheric temperatures, indicate the openness of the aquifer system, thereby its vulnerability to pollution $[3,55]$. These results justify the high percentage of dissolved oxygen (DO) ranging between $2.33 \%$ and $6.12 \%$ overall seasons in the study area. The waters in the study area are acidic with mean values of $5.90 \pm 1.32,5.14 \pm 0.52,5.83 \pm 0.9$, and $5.27 \pm 0.53$ for LRS, SDS, SRS, and LDS, respectively. This acidity is more pronounced during the dry seasons compared to the rainy seasons. The acidic nature of the waters in Côte d'Ivoire is highlighted by the researchers on the groundwater $[2$, $27,52,61]$. In the municipality of Treichville, the acidic nature of the water can be related to the geology of the aquifer. Indeed, according to Kouame [27], the acidity of groundwater is linked to the presence of high content of free $\mathrm{CO}_{2}$. This is due to the constant presence of organic matter linked to the infiltration of humic acids. As the sand is low in basic elements (Ca, Mg), the acidity is preserved. The acidic nature of the water can be related also by the organic matter coming from human activities with strong 


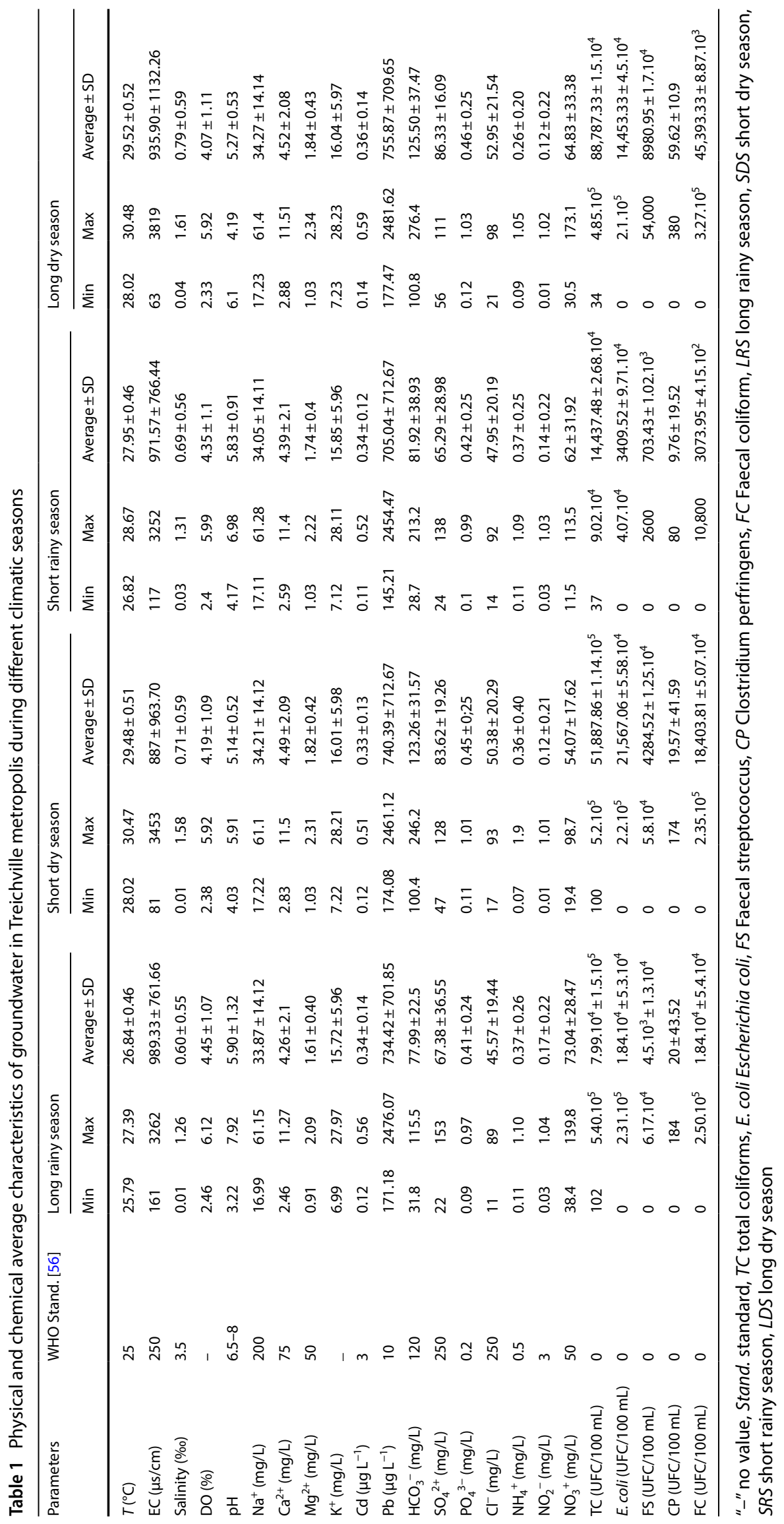


groundwater contamination due, according to Yapo et al. [60], to the infiltration of domestic wastewater.

For groundwater, conductivity is directly related to the concentration of ions present in it. Higher conductivity may be attributed to high salinity and high mineral percentage in groundwater samples, which are generally due to the ion exchange and solubilization process taking place within the aquifers $[9,51]$. The global EC values ranged from 63 to $3819 \mu \mathrm{S} / \mathrm{cm}$ with averages of $989.33 \pm 761.66$ $\mu \mathrm{S} / \mathrm{cm}, 887 \pm 963.70 \mu \mathrm{S} / \mathrm{cm}, 971.57 \pm 766.44 \mu \mathrm{S} / \mathrm{cm}$ and $935.90 \pm 1132.26 \mu \mathrm{S} / \mathrm{cm}$ for LRS, SDS, SRS, and LDS, respectively. Based on the electrical conductivity of the water (Table 2), the results show that $71 \%$ of the wells consist of freshwater $(<1000 \mu \mathrm{S} / \mathrm{cm})$ during the rainy seasons (LRS and SRS), and only $67 \%$ of freshwater during the dry seasons (LDS and SDS). It is also noted that the waters of the Treichville municipality are slightly saline (1000-3000 $\mu \mathrm{S} /$ $\mathrm{cm})$, with a proportion of $24 \%$ during the rainy seasons, whereas this proportion is $24 \%$ and $28 \%$, respectively, for the SDS and LDS. Also, nearly $5 \%$ of water over 3 seasons and $9 \%$ during the LDS are moderately saline $(3000-10,000$ $\mu \mathrm{S} / \mathrm{cm})$. Of the samples, a proportion of $29-33 \%$ can be classified as dangerous according to $\mathrm{WHO}$ [56].

Parameters, such as $\mathrm{Na}^{+}, \mathrm{Ca}^{2+}, \mathrm{Mg}^{2+}, \mathrm{K}^{+}, \mathrm{Cd}_{1} \mathrm{HCO}_{3}{ }^{-}$, $\mathrm{PO}_{4}{ }^{3-}, \mathrm{SO}_{4}{ }^{2-}, \mathrm{Cl}^{-}, \mathrm{NH}_{4}{ }^{+}$and $\mathrm{NO}_{2}{ }^{-}$, have values below the $\mathrm{WHO}$ [56] guideline values in all seasons. On the other hand, the range of $\mathrm{Pb}$ is observed between $171 \mu \mathrm{g} \mathrm{L} \mathrm{L}^{-1}$ (LRS) and $2980 \mu \mathrm{g} \mathrm{L}^{-1}$ (SRS) and $\mathrm{NO}_{3}^{+}$is ranged between $38.4 \mathrm{mg} \mathrm{L}^{-1}$ (SRS) and $173.1 \mathrm{mg} \mathrm{L}^{-1}$ (SDS), indicating that some locations exceed the limit for drinking water consumption $\left(50 \mathrm{mg} \mathrm{L}^{-1}\right)$. Also, the highest TC, E. coli, and FS values $\left(540,000,231,000\right.$, and 61,700 CFU $\left.100 \mathrm{~mL}^{-1}\right)$ are obtained during the LRS. For $\mathrm{CP}$ and $\mathrm{FC}$, the highest value (380 and 327,000 CFU. $100 \mathrm{~mL}^{-1}$ ) is obtained in the LDS. High concentrations of $\mathrm{Pb}, \mathrm{NO}_{3}{ }^{-}$and bacteriological parameters indicate that these parameters have values above the WHO [56] guideline values in the considered seasons. The high concentrations of nitrates expose well water consumers to health risks such as methaemoglobinaemia, reduced thyroid function, and cancer according to many authors $[4,17,18,20]$. Also, high lead concentrations in groundwater pose significant risks to consumers. Indeed, in most research $[36,46,56]$, it is indicated that increased blood $\mathrm{Pb}$ concentration affects behaviour, cognitive performance, postnatal growth, delays puberty and reduces the hearing ability of infants and children. In adults, $\mathrm{Pb}$ causes cardiovascular, central nervous system, kidney, fertility, and cancer problems. Concerning microbiological parameters, the high concentrations reveal that the low-income populations are exposed to diseases such as cholera, diarrhoea, typhoid fever, gastrointestinal infections according to Fallahzadeh et al. [19] and He et al. [23], due to the high presence of bacteriological germs in the waters.

\subsection{Statistical distribution of main parameters (nitrate, lead, sulphate, and Escherichia coli)}

The nonparametric Kruskal-Wallis test indicates that the seasonal variation of nitrate, lead and $E$. coli was not significant ( $T K W: p>0.05$ ). The low seasonal variation of these parameters indicates that the seasonal variation has a minor influence on concentrations. The water temperature values recorded for all wells range from $25.79^{\circ} \mathrm{C}$ for LRS to $30.49{ }^{\circ} \mathrm{C}$ for LDS. This water temperature is favourable for microbial growth because according to Djaouda et al. [12], a water temperature between 25 and $28{ }^{\circ} \mathrm{C}$ is good for microbial growth. Water temperature is an important factor in the metabolism of aquatic organisms. Indeed, it affects the physical and chemical

Table 2 Water quality classification for various ranges of EC in $\mu \mathrm{S} / \mathrm{cm}$

\begin{tabular}{|c|c|c|c|c|c|c|c|c|c|}
\hline \multirow{2}{*}{$\begin{array}{l}\text { Ranges of } \\
E C(\mu S / \mathrm{cm})\end{array}$} & \multirow{2}{*}{$\begin{array}{l}\text { Classifica- } \\
\text { tion [9] }\end{array}$} & \multicolumn{2}{|l|}{ LRS } & \multicolumn{2}{|l|}{ SDS } & \multicolumn{2}{|l|}{ SRS } & \multicolumn{2}{|l|}{ LDS } \\
\hline & & $\begin{array}{l}\text { Water sam- } \\
\text { ples }\end{array}$ & $\begin{array}{l}\text { Percentage } \\
\text { of samples } \\
\text { (\%) }\end{array}$ & $\begin{array}{l}\text { Samples } \\
\text { number }\end{array}$ & $\begin{array}{l}\text { Percentage } \\
\text { of samples } \\
(\%)\end{array}$ & $\begin{array}{l}\text { Samples } \\
\text { number }\end{array}$ & $\begin{array}{l}\text { Percentage } \\
\text { of samples } \\
(\%)\end{array}$ & $\begin{array}{l}\text { Water sam- } \\
\text { ples }\end{array}$ & $\begin{array}{l}\text { Percentage } \\
\text { of samples } \\
(\%)\end{array}$ \\
\hline$<1500$ & Permissible & $\begin{array}{r}\text { P7, P8, P9, } \\
\text { P21, P10, } \\
\text { P11, P12, } \\
\text { P13, P14, } \\
\text { P15, P16, } \\
\text { P17, P18, } \\
\text { P19, P20 }\end{array}$ & 71 & $\begin{array}{c}\text { P5, P6, P8, } \\
\text { P9, P10, } \\
\text { P11, P13, } \\
\text { P15, P16, } \\
\text { P17, P18, } \\
\text { P19, P20, } \\
\text { P21 }\end{array}$ & 67 & $\begin{array}{r}\text { P7, P8, P9, } \\
\text { P10, P11, } \\
\text { P12, P13, } \\
\text { P14, P15, } \\
\text { P16, P17, } \\
\text { P18, P19, } \\
\text { P20, P21 }\end{array}$ & 71 & $\begin{array}{l}\text { P5, P6, P7, } \\
\text { P8, P9, } \\
\text { P10, P11, } \\
\text { P13, P15, } \\
\text { P16, P17, } \\
\text { P19, P20, } \\
\text { P21 }\end{array}$ & 67 \\
\hline $1500-3000$ & $\begin{array}{l}\text { Not permis- } \\
\text { sible }\end{array}$ & $\begin{array}{l}\text { P1, P2, P4, } \\
\text { P5, P6 }\end{array}$ & 24 & $\begin{array}{l}\text { P1, P2, 12, } \\
\text { P7, P4, P14 }\end{array}$ & 28 & $\begin{array}{l}\text { P6, P1, P2, } \\
\text { P5, P4 }\end{array}$ & 24 & $\begin{array}{l}\text { P1, P2, P4, } \\
\text { P12, P18, }\end{array}$ & 24 \\
\hline$>3000$ & Hazardous & P3 & 5 & P3 & 5 & P3 & 5 & P3, P14 & 9 \\
\hline
\end{tabular}

$p<0.05$ : statistically significant differences 
properties of water, in particular its density, viscosity, the solubility of its gas, and the rate of chemical and biochemical reactions [12]. However, there are statistically significant differences (TKW: $p<0.05$ ) regarding sulphate during the seasons. Mann-Whitney test realized on sulphate indicates that the difference is between the dry season and the rainy season. Indeed, the highest values are accentuated in the dry season (Fig. 3). This seasonal variation of sulphate concentration shows that these concentrations would be linked to rainfall. The low concentrations observed during the rainy season would, therefore, result from dilution of the pollutant by the infiltration of rainwater into the groundwater.

Concerning the spatial variation of these different parameters, the nonparametric Kruskal-Wallis test showed a significant difference $(T K W: p<0.05)$ between the different wells sampled for each of the parameters $\left(\mathrm{NO}_{3}{ }^{+}, \mathrm{Pb}, \mathrm{SO}_{4}{ }^{2-}\right.$, and $\mathrm{E}$. coli). The Man-Whitney test carried out on these parameters gives the results presented in Tables 3, 4, 5 and 6. Wells are different from each other regarding $E$. coli, sulphate, nitrate, and lead. However, compared to $E$. coli and $\mathrm{Pb}$ this difference between wells is less for $\mathrm{NO}_{3}{ }^{+}$and $\mathrm{SO}_{4}{ }^{2-}$. The difference observed between the wells indicates that pollution is punctual. The source of the pollutant would, therefore, be punctual. The non-significant difference observed between some wells would show diffuse pollution. Thus, well water would be under the influence of point and diffuse pollution by nitrate and sulphate (Tables 4 and 5) and under the influence of point source pollution by $\mathrm{Pb}$ and E. coli (Tables 3 and 6).

\subsection{Factors influencing the groundwater mineralization}

The mineralization was studied using the Kohonen maps shown in Figs. 4 and 5. From these figures, it can be seen that four groups of water emerge as a function of the predominance of physicochemical and bacteriological parameters. The waters in groups I and IV cover water samples taken from wells near the Ebrié Lagoon (Biafra, Nanan Yamousso area, and the great market area). These waters are characterized by high salinity (maximum: $1.24 \%$ ) and by high concentrations of cadmium (maximum: $2140 \mu \mathrm{g} \mathrm{L}^{-1}$ ), lead (maximum: $2140 \mu \mathrm{g} \mathrm{L}^{-1}$ ) and magnesium (maximum: $2.02 \mathrm{mg} \mathrm{L}^{-1}$ ). Water in the wells near the Ebrié Lagoon is salty. This indicates that there is an exchange between the lagoon and the groundwater. Douagui et al. [14] found similar results on the quaternary groundwater. In these areas, the positive correlation between salinity, $\mathrm{Cd}, \mathrm{Pb}_{2} \mathrm{PO}_{4}{ }^{3-}$, and $\mathrm{SO}_{4}{ }^{2-}$ shows a common origin and would come from the lagoon that receives the city's wastewater. In fact, according to Tuo et al. [29] and Kouamenan et al. [28], the Ebrié Lagoon in Abidjan is subject to industrial and domestic waste inputs. Its proximity to the water table would facilitate the intrusion of lagoon water into the groundwater. Ben Abbou et al. [8] found similar results on groundwater in Taza Province (Morocco). The authors' works have highlighted the pollution of some sources that are said to originate from the proximity of these sources to the rivers that receive wastewater from the city of Taza.
Fig. 3 Temporal variability of nitrate, lead, sulphate, and Escherichia coli
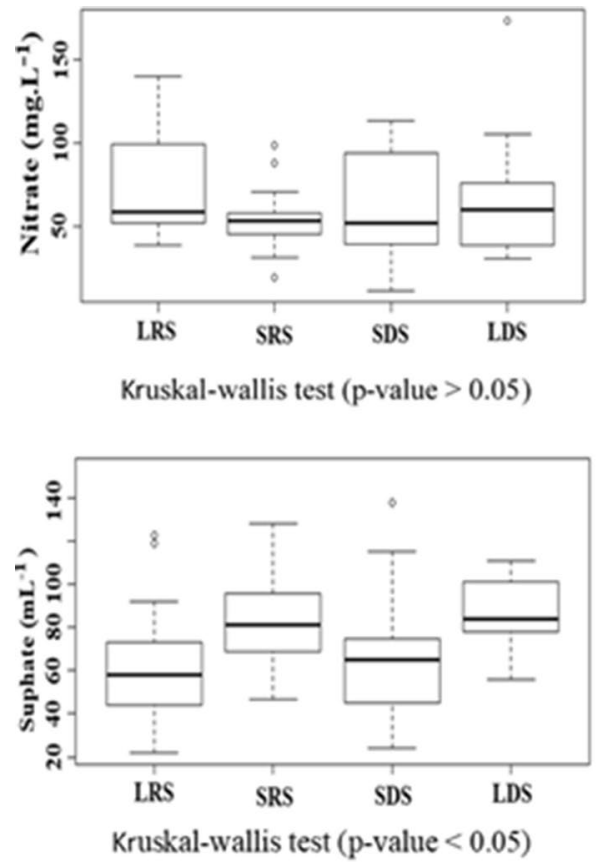
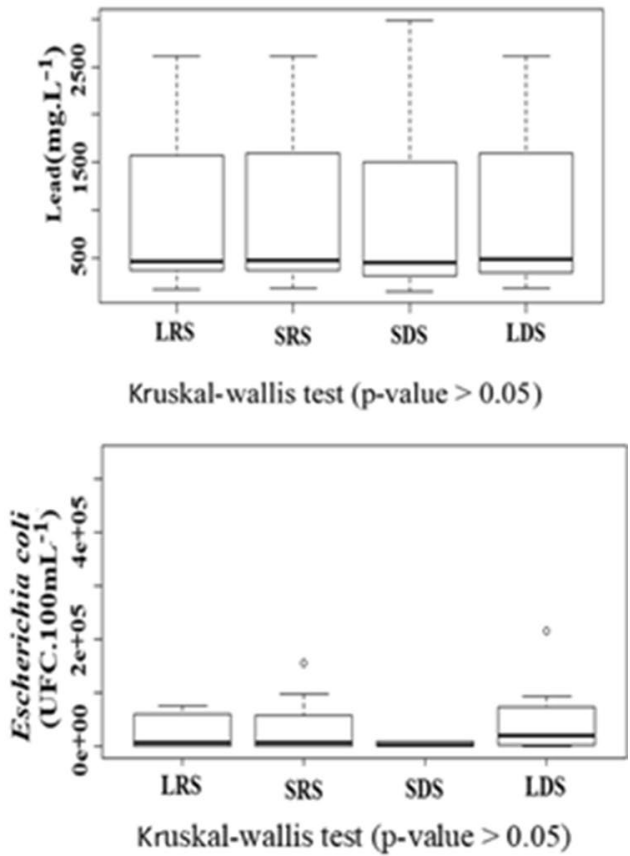

SN Applied Sciences A SPRINGER NATURE journa 


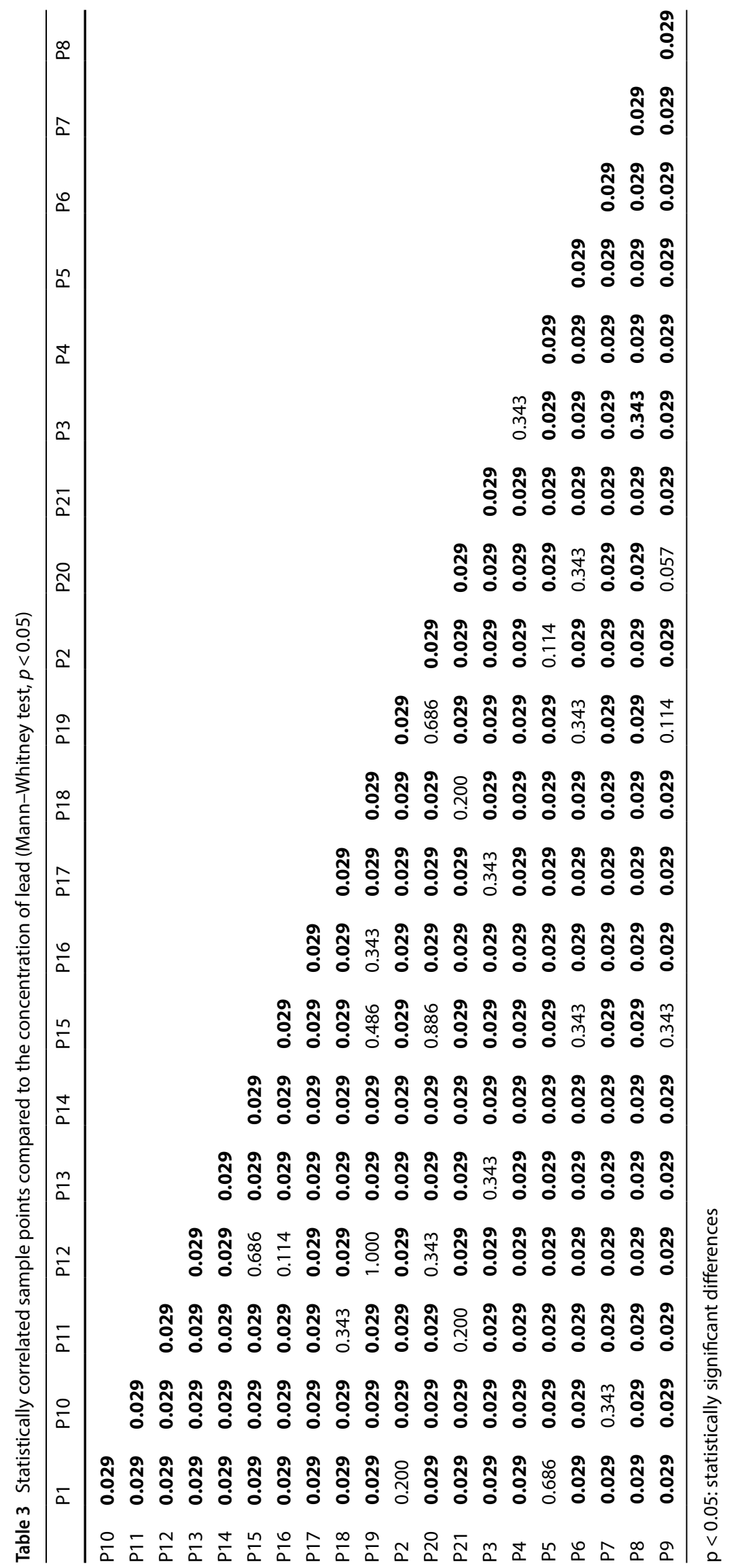




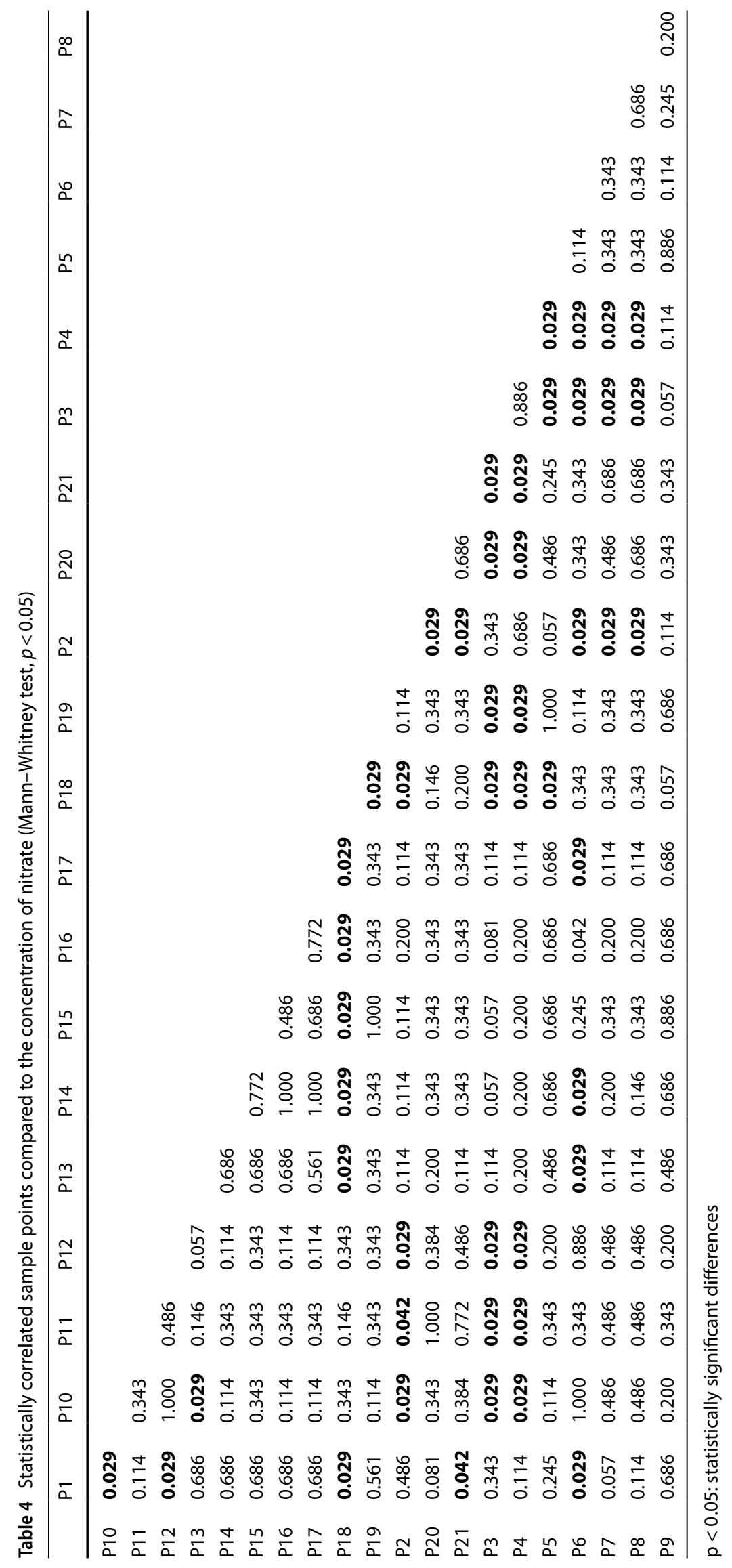




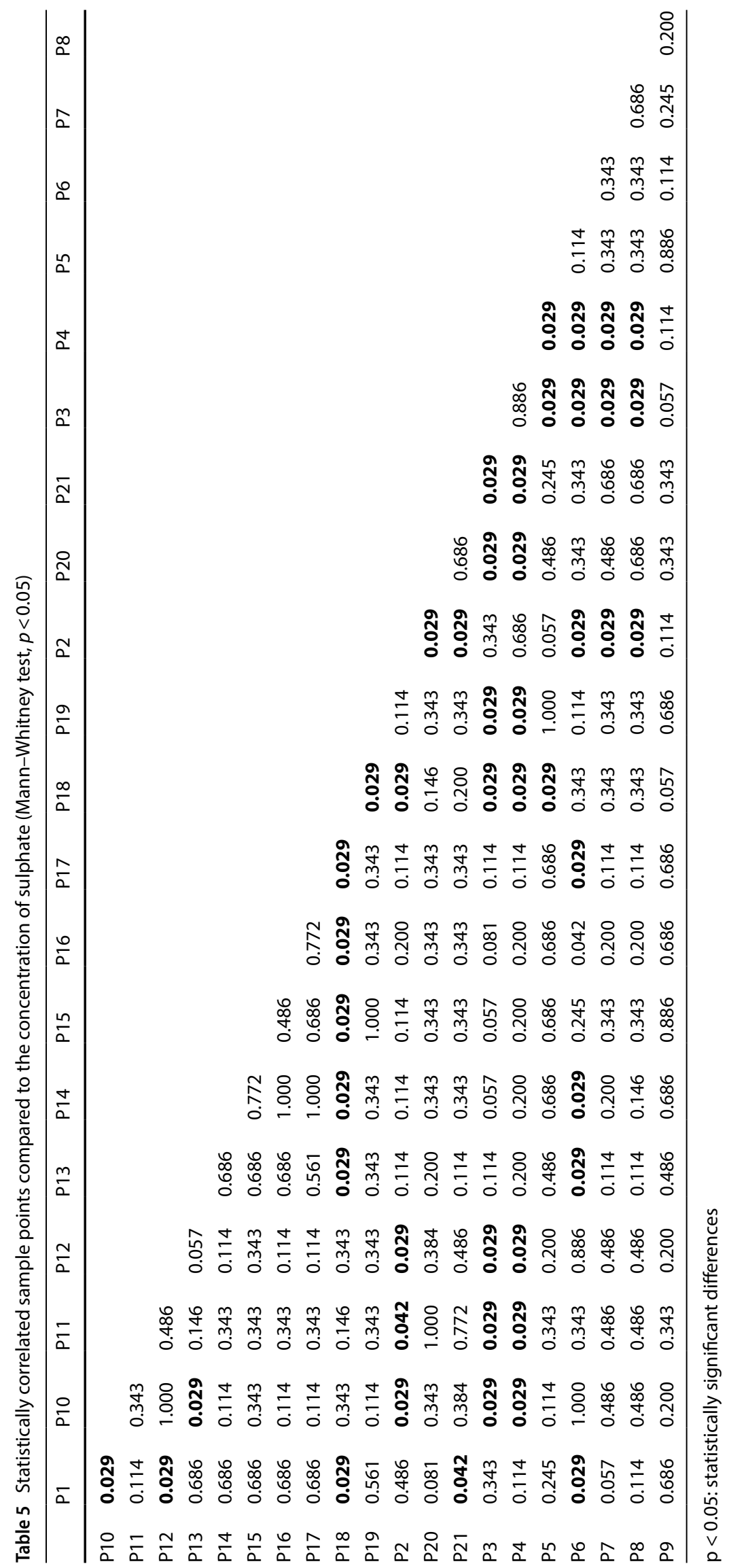




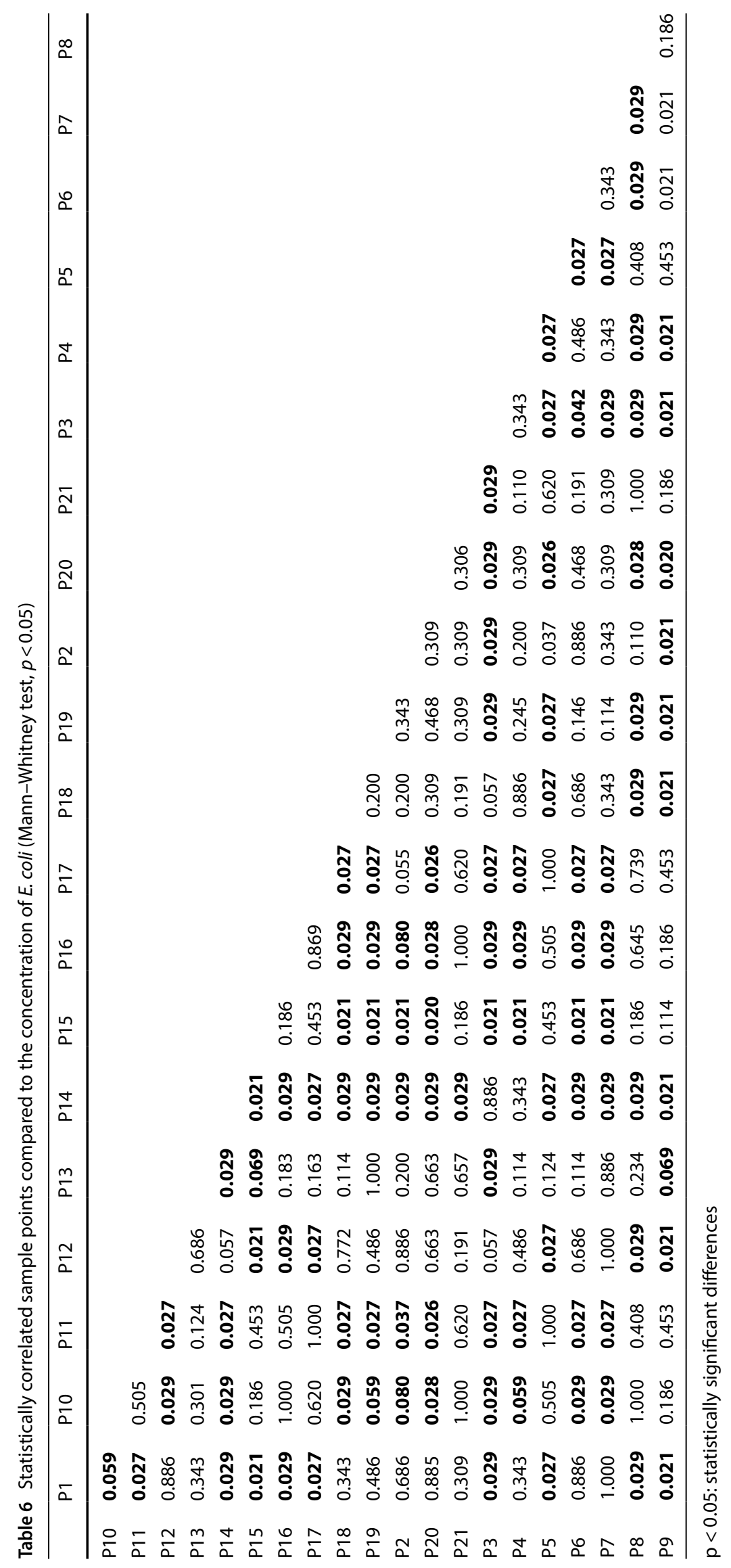




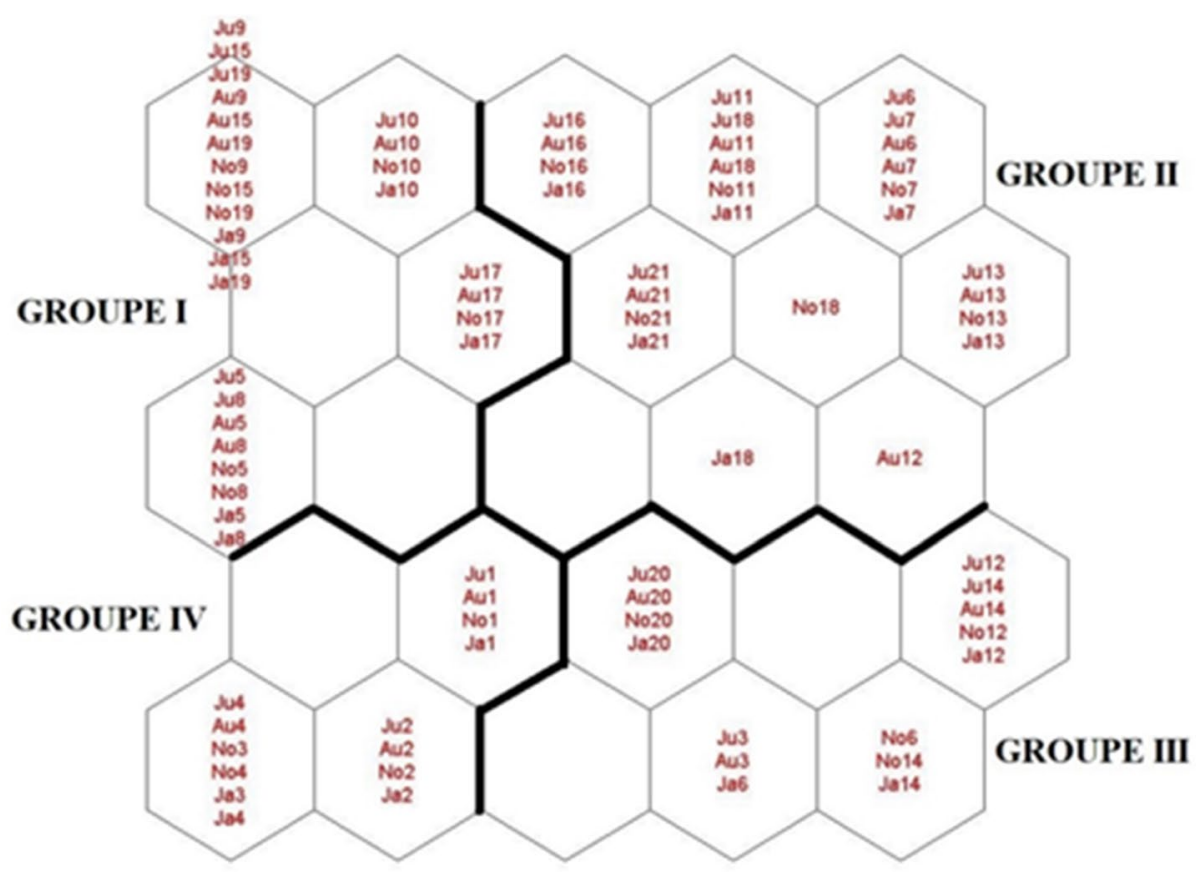

Ju, Au, No and Ja correspond to samples taken in Jine, August, November 2018 and Jamuary 2019 respectively; vahes ranging from 1 to 21 correspond to the numbers of sampling points

Fig. 4 Samples distribution on the Kohonen map based on physicochemical and bacteriological variables

However, parameters such as $\mathrm{Na}^{+}, \mathrm{K}^{+}, \mathrm{Cd}, \mathrm{Pb}, \mathrm{PO}_{4}{ }^{3-}$, $\mathrm{SO}_{4}{ }^{2-}$, and $\mathrm{NO}_{3}{ }^{-}$may be used to distinguish between groups I and IV (Figs. 4 and 5). Thus, the majority of the water in group IV, which comes mainly from wells in the vicinity of Biafra (P1, P2, P3 and P4), is richer in $\mathrm{Na}^{+}, \mathrm{K}^{+}$, $\mathrm{PO}_{4}{ }^{3-}, \mathrm{NO}_{3}{ }^{-}, \mathrm{Cd}, \mathrm{Pb}$, and $\mathrm{SO}_{4}{ }^{2-}$ (Fig. 5). However, the mineralization of water from these wells is mainly related to $\mathrm{PO}_{4}{ }^{3-}$ and $\mathrm{NO}_{3}{ }^{-}$, which show significant correlations with electrical conductivity (Table 7). Significant correlations are also obtained between salinity and $\mathrm{NO}_{3}{ }^{-}, \mathrm{PO}_{4}{ }^{3-}, \mathrm{Cd}$, $\mathrm{Pb}$, and $\mathrm{SO}_{4}{ }^{2-}$ ions and between salinity and conductivity (Table 7). This significant enrichment of groundwater in $\mathrm{NO}_{3}{ }^{-}, \mathrm{PO}_{4}{ }^{3-}, \mathrm{Cd}, \mathrm{Pb}$, and $\mathrm{SO}_{4}{ }^{2-}$ could be caused either by the infiltration of anthropogenic wastewater through an advection mechanism or by the lateral contamination of water from septic tanks and latrines located near wells through a diffusion mechanism. These results are in agreement with those of several authors who have worked on well waters $[1,11]$.

Biafra has many automechanics garages. These activities generate waste oils and fuel that are believed to cause high concentrations of lead in the groundwater. Similar results were found by Ahoudi et al. [1] in a study in the Agoè-Zongo district in southern Togo. These authors reported high lead concentrations in groundwater. The origins of this lead have been attributed to the many leaks of oil, fuel, and battery acid from the garage of the Lomé autonomous port. The high concentration of lead in Biafra neighbourhood is also due to the many informal activities there. Indeed, in Biafra, there are important depots of paint, barrels of chemical products, and artisanal bitumen manufacturing that might be capable of releasing lead that will seep into the groundwater with the rainwater. An anthropogenic origin of lead in groundwater has also been obtained with Egbueri and Mgbenu [16] in the Ojoto Province, southeast Nigeria.

The waters of group III (Fig. 4), of which most of the wells (P3, P6, P12, P14) are located in the NE-SW direction (direction including the Biafra, Nanan Yamousso and Appolo districts) are characterized by high contents of $\mathrm{HCO}_{3}{ }^{-}, \mathrm{Cl}^{-}$and $\mathrm{NO}_{3}{ }^{-}$ions and also TC, E. coli, FS, CP, and FC (Fig. 5). There is a positive and significant correlation between these ions, bacteria, and electrical conductivity (Table 7). This correlation indicates an anthropogenic origin of water mineralization in this area. Wastewater from latrines, septic tanks, and sewage drains would be at the origin of this mineralization. Indeed, according to many authors [21, 22], $\mathrm{Cl}^{-}, \mathrm{NO}_{3}{ }^{-}$, and $\mathrm{EC}$ are indicators of wastewater pollution. Groundwater 

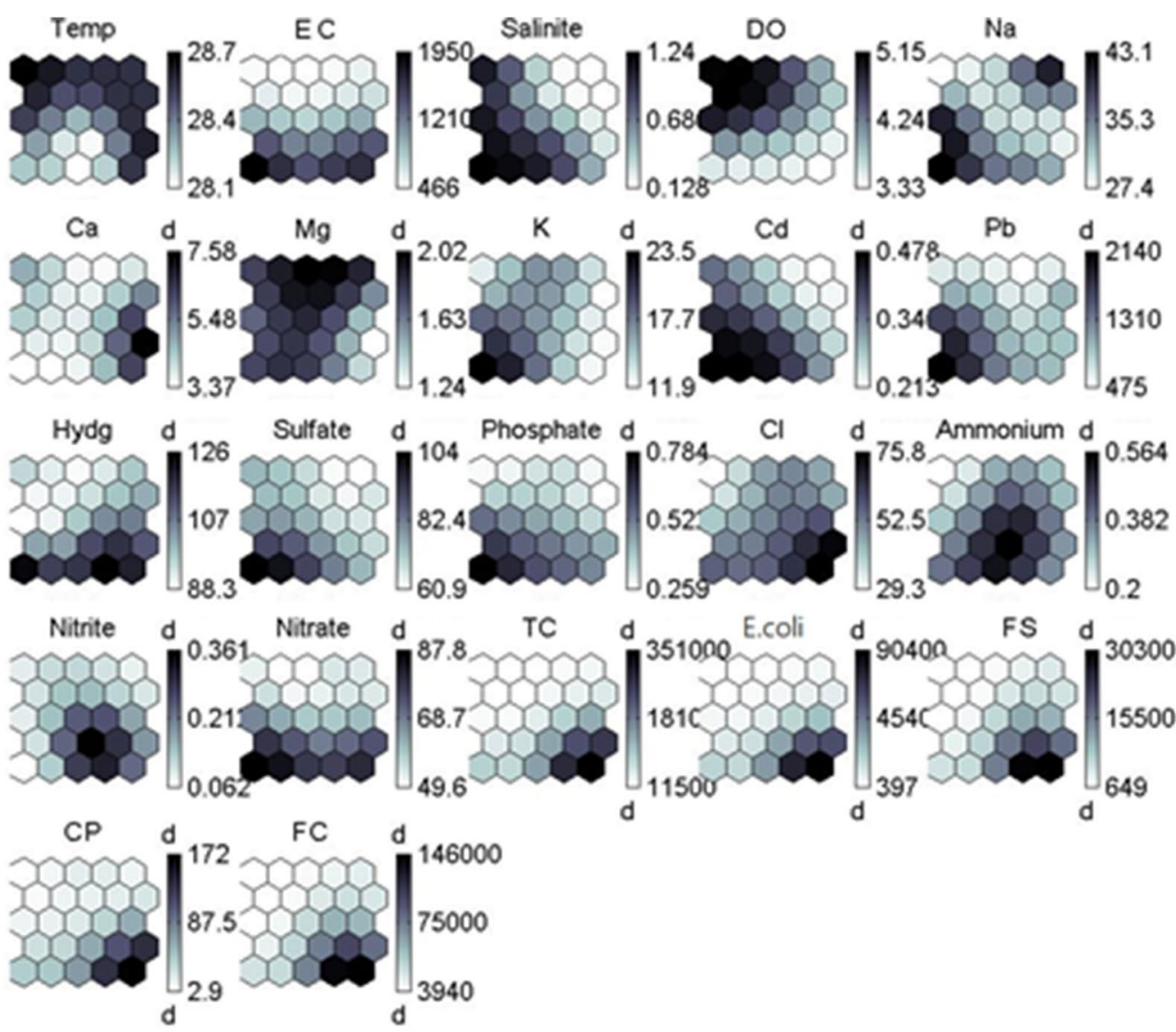

Temp = temperature $; E C=$ electrical conductivity $\left(\mu \mathrm{S} . \mathrm{cm}^{-1}\right) ; D O=$ dissolved oxygen; Hydg = hydrogen carbonate $\left(\mathrm{mg} \cdot \mathrm{L}^{-1}\right) ; T C=$ total coliforms $\left(\right.$ UFC.100 mL $\left.\mathrm{L}^{-1}\right)$;

E. coli $=$ Escherichia coli $\left(U F C .100 \mathrm{~mL}^{-1}\right) ; F S=$ Fecal Streptococcus $\left(U F C .100 \mathrm{~mL}^{-1}\right)$; $C P=$ Clostridium perfingens $\left(U F C .100 \mathrm{~mL}^{-1}\right) ; F C=$ Fecal Coliform $\left(U F C .100 \mathrm{~mL}^{-1}\right)$

Fig. 5 Gradient of values of the analytical parameters on the Kohonen map

contamination in the study area would be caused by the lateral migration of pollutants from septic tanks and latrines due to lateral water circulation.

Group II waters are lower in mineralization than the other groups (Fig. 4). These waters are characterized by high temperature and a high concentration of $\mathrm{Na}^{+}$and $\mathrm{Mg}^{2+}$ ions (Fig. 5). This grouping reflects a mechanism of dissolution of the clay component of the clayey-sandy layers when the water temperature rises. This mechanism seems to be permanent since it occurs in all seasons. The results agree with those of Douagui et al. [14] who showed the existence of clay-sand layers in the Quaternary aquifer in the municipality of Treichville.

\subsection{Relationship between the water table and the spatial and the temporal distribution of nitrate and Escherichia coli concentration in the groundwater}

The groundwater flow map overall seasons describes a convergence of flows in the NE-SW direction from Biafra. According to the spatial distribution maps of nitrates (Figs. 6), the highest nitrate concentrations are found in Biafra during the rainy season and in the NE-SW direction in the dry season. According to the Escherichia coli spatial distribution maps (Fig. 7), the highest concentrations are 
Table 7 Significant ( $\mathrm{ns}<0.05$ ) Spearman correlation coefficients $(\mathrm{ns}<0.05)$ between physical, chemical, and bacteriological parameters

\begin{tabular}{|c|c|c|c|c|c|c|c|c|c|c|c|c|c|c|c|c|}
\hline & $\mathrm{CE}$ & Sal & $\mathrm{Na}$ & $\mathrm{K}$ & $\mathrm{Cd}$ & $\mathrm{Pb}$ & Hyd & Sul & $\mathrm{Ph}$ & $\mathrm{Cl}^{-}$ & $\mathrm{NO}_{3}^{-}$ & CT & E. coli & SF & $\mathrm{CP}$ & $\mathrm{CF}$ \\
\hline EC & 1 & & & & & & & & & & & & & & & \\
\hline Sal & $0.24^{*}$ & 1 & & & & & & & & & & & & & & \\
\hline $\mathrm{Na}$ & $0.25^{*}$ & $0.23^{*}$ & 1 & & & & & & & & & & & & & \\
\hline $\mathrm{K}$ & $0.28^{*}$ & $0.23^{*}$ & $0.56^{* *}$ & 1 & & & & & & & & & & & & \\
\hline $\mathrm{Cd}$ & $0.30^{* *}$ & $0.65^{* *}$ & - & - & 1 & & & & & & & & & & & \\
\hline $\mathrm{Pb}$ & $0.33^{* *}$ & $0.46^{* *}$ & - & $0.22^{*}$ & $0.61^{* *}$ & 1 & & & & & & & & & & \\
\hline Hyd & - & $0.33^{* *}$ & - & - & - & - & 1 & & & & & & & & & \\
\hline Sul & - & $0.40^{* *}$ & - & - & $0.47^{* *}$ & $0.56^{* *}$ & $0.39^{* *}$ & 1 & & & & & & & & \\
\hline $\mathrm{Ph}$ & $0.45^{* *}$ & $0.43^{* *}$ & $0.28^{*}$ & $0.54^{* *}$ & $0.48^{* *}$ & $0.51^{* *}$ & $0.24^{*}$ & $0.40^{* *}$ & 1 & & & & & & & \\
\hline $\mathrm{Cl}^{-}$ & $0.41^{* * *}$ & - & $0.26^{*}$ & $0.24^{*}$ & - & - & $0.26^{*}$ & - & $0.47^{* *}$ & 1 & & & & & & \\
\hline $\mathrm{NO}_{3}^{-}$ & $0.74^{* *}$ & $0.22^{*}$ & 0.32 & $0.25^{*}$ & - & $0.26^{*}$ & - & $0.24^{*}$ & $0.47^{* *}$ & $0.36^{* *}$ & 1 & & & & & \\
\hline CT & $0.34^{* *}$ & - & - & - & - & - & $0.45^{* *}$ & - & $0.30^{*}$ & $0.45^{* *}$ & - & 1 & & & & \\
\hline E. coli & $0.43^{* *}$ & - & $0.23^{*}$ & - & - & - & $0.43^{* *}$ & - & $0.28^{*}$ & $0.60^{* *}$ & $0.29 *$ & $0.79^{* *}$ & 1 & & & \\
\hline SF & $0.31^{* *}$ & - & $0.27^{*}$ & - & - & - & $0.47^{* *}$ & - & $0.30^{*}$ & $0.44^{* *}$ & - & $0.83^{* *}$ & $0.80^{* *}$ & 1 & & \\
\hline $\mathrm{CP}$ & $0.24^{*}$ & - & - & - & - & - & $0.27^{*}$ & - & $0.23^{*}$ & $0.41^{* *}$ & - & $0.50^{* *}$ & $0.52^{* *}$ & $0.48^{* *}$ & 1 & \\
\hline $\mathrm{CF}$ & $0.29^{*}$ & - & $0.27^{*}$ & - & - & - & $0.49^{* *}$ & - & $0.29^{*}$ & $0.44^{* *}$ & - & $0.83^{* *}$ & $0.80^{* *}$ & $1.00^{* *}$ & $0.48^{* *}$ & 1 \\
\hline
\end{tabular}

$\mathrm{p}>0.05 ;{ }^{*} \mathrm{p}<0.05$ pour $0.165 \leq|r|<0.301 ;{ }^{* *} \mathrm{p}<0.01$ pour $|r| \geq 0.301$

$\mathrm{EC}=$ electrical conductivity; Sal: salinity; hydg=hydrogen carbonate; Sul: sulphate; Phos: phosphate; CT: total coliforms; E. coli=Escherichia coli; SF =Faecal Streptococcus; CP: Clostridium perfringens; CF: Faecal coliform. - : $p>0.05 ;{ }^{*}: p<0.05$ for $0.165 \leq: p<0.301 ;{ }^{* *}: p<0.01$ for 0.301

observed more in the dry season. They are mainly concentrated in Biafra (north-east) and on the water flow line.

Indeed, the pollutants in the water leave the Biafra neighbourhood and are carried by the water to the South. The water flows in a north-eastern and southwestern direction with a net from the Biafra neighbourhood, where the pollution is more intense. During the water's flow, the pollution is amplified by the presence of septic tanks and latrines located on the flow line. However, there is a seasonal differentiation. Indeed, during the rainy season, pollution is lower in EC and nitrates than during the dry season. This is probably due to the dilution by rainwater of groundwater, which is superficial and recharges quickly. These results are in concordance with those of Njueya et al. [47] in the Douala sedimentary basin (Cameroon). Indeed, the authors have highlighted the poor quality of some wells for microorganisms during the dry season and fairly good quality during the rainy season. It is found that during the rainy season, there is a dilution effect that reduces the concentration of bacteria in the water.

\section{Conclusions}

Groundwater in the Municipality of Treichville is generally of poor quality. The groundwater contains nitrate, phosphate, and leads ions, as well as concentrations of faecal coliforms, total coliforms, Escherichia coli, and faecal streptococci over the WHO standard for drinking water. Anthropogenic pollution indicators such as phosphate, nitrate, sulphate, and lead are correlated with electrical conductivity. This indicates that the groundwater mineralization is of anthropogenic origin.

The pollutants responsible for the mineralization are from a point and diffuse sources. The pollutant transfer is continuous and the pollution is persistent in the environment. The mineralization mainly comes from human activities in Biafra neighbourhood and extends to other neighbourhoods (Nanan Yamousso, Appolo, Notre Dame) according to the direction of the water flow. The main factors influencing water quality are the lagoon water intrusion, the advection mechanism linked to the infiltration of surface water and the lateral migration of pollutants from septic tanks and latrines, and mechanism of dissolution of the clay component of the clayey-sandy layers. Measures must be taken by the decision-maker to ensure that poor people have access to tap water at the risk of contracting serious waterborne diseases. The subscription of low-income 

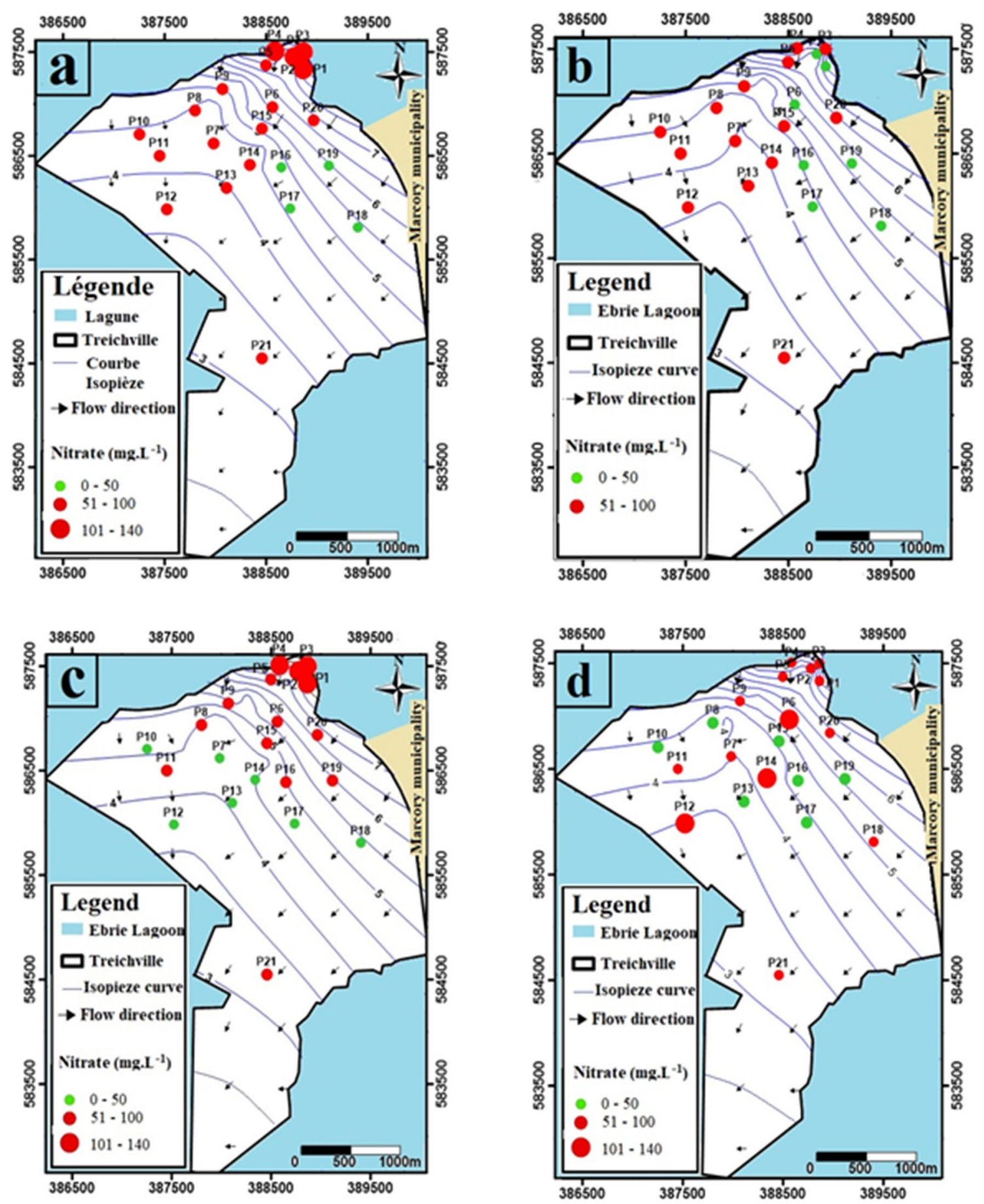

Fig. 6 Nitrate content of waters during the seasons (long rainy season (a), short dry season (b), short rainy season (c), long dry season (d)

populations to social water meters by the government is one of the solutions to enable these deprived populations to have permanent access to drinking water. Also, awareness campaigns on the risks related to the consumption of well water by the municipality of Treichville could reduce the risk of contamination of the population with waterborne diseases. 

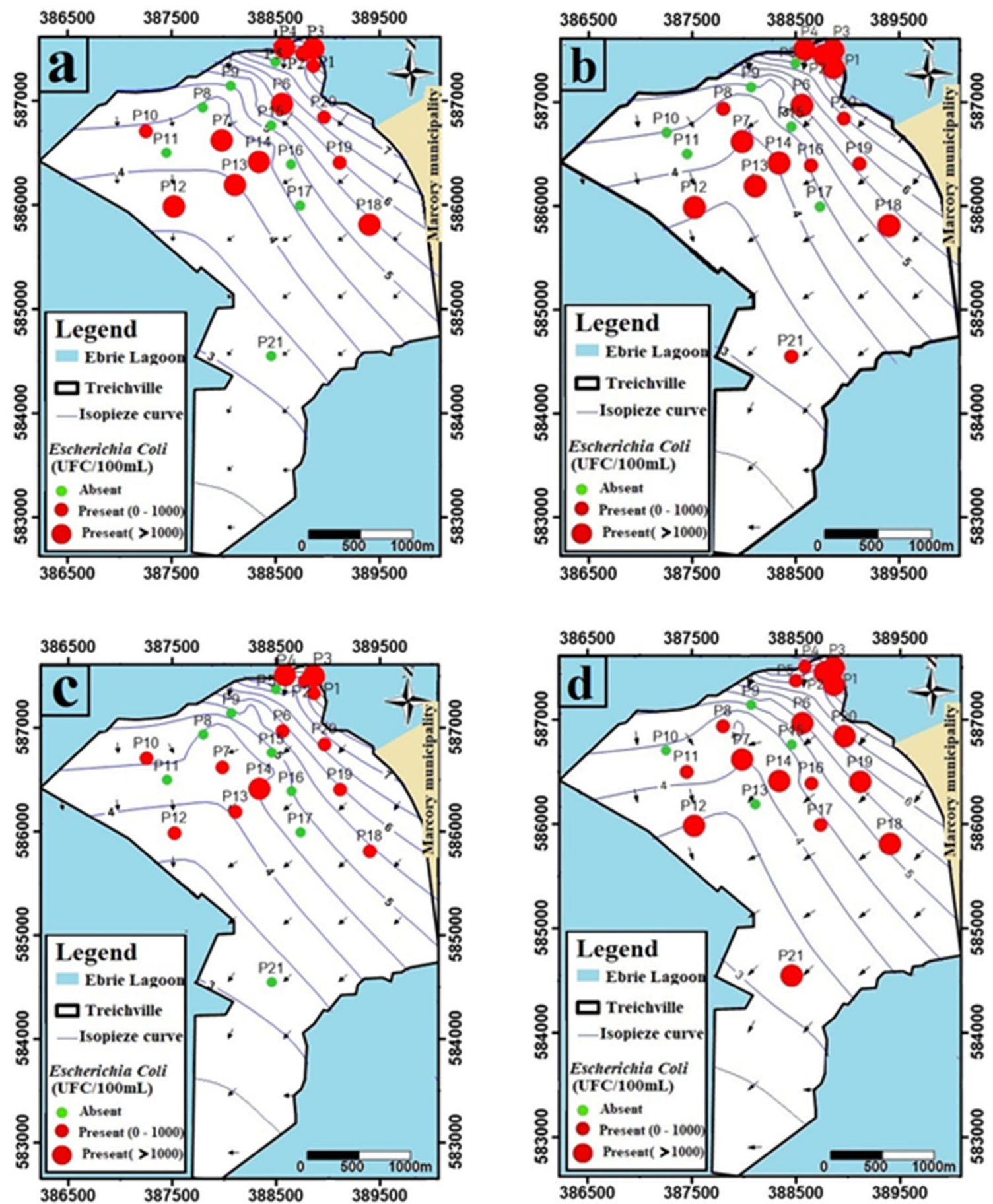

Fig. 7 Escherichia coli content of waters during the seasons (long rainy season (a), short dry season (b), short rainy season (c), long dry season (d) 


\section{Compliance with ethical standards}

Conflict of interest The authors confirm that there's no conflict of interest.

\section{References}

1. Ahoudi H, Gnandi K, Tanouayi G, Ouro-sama K (2015) Caractérisation physico-chimique et état de pollution par les éléments traces métalliques des eaux souterraines de Lomé (sud Togo): cas du quartier Agoe zongo. Larhyss J 24:41-56

2. Ahoussi KE, Koffi YB, Kouassi AM, Soro G, Biemi J (2013) Hydrochemical and microbiological study of spring waters in the west mountainous region of Ivory Coast: case of the village of Mangouin-Yrongouin (sub-prefecture of Biankouman). J Appl Biosci 63:4703-4719

3. Ahoussi KE, Oga YMS, Koffi YB, Kouassi AM, Soro N, Biemi J (2011) Hydrogeochemical and microbiological characterization of water resources at the site of a Technical Burial Centre (CET) in Côte d'Ivoire: case of the CET of Kossihouen in the District of Abidjan (Côte d'Ivoire). Int J Biol Chem Sci 5(5):2114-2132

4. Almasri MN (2007) Nitrate contamination of groundwater: a conceptual management framework. Environ Impact Assess Rev 27(3):220-242. https://doi.org/10.1016/j.eiar.2006.11.002

5. Ambarref M, Saadia A, Bernoussi AS, Haddouchi BY (2007) Mapping vulnerability to groundwater pollution: application to the Gharb plain (Morocco). Rev Sci Eau 20(2):185-199. https://doi. org/10.7202/015812ar

6. Asare-Donkor NK, Boadu TA, Adimado AA (2016) Evaluation of groundwater and surface water quality and human risk assessment for trace metals in human settlements around the Bosomtwe Crater Lake in Ghana. SpringerPlus 5:1812. https:// doi.org/10.1186/s40064-016-3462-0

7. Ayotte JD, Belaval M, Olson SA, Burow KR, Flanagan SM, Hinkle SR, Lindsey BD (2015) Factors affecting temporal variability of arsenic in groundwater used for drinking water supply in the United States. Sci Total Environ 505:1370-1379. https://doi. org/10.1016/j.scitotenv.2014.02.057

8. Ben Abbou M, El Haji M, Zemzami M, Fadil F (2013) Détermination de la qualité des eaux souterraines des nappes de la province de Taza (Maroc). Larhyss J 16:77-90

9. Bozdag A, Gocmez G (2013) Evaluation of groundwater quality in the Cihanbeyli basin, Konya, Central Anatolia, Turkey. Environ Earth Sci 69:921-937. https://doi.org/10.1007/s1266 5-012-1977-4

10. Chotpantarat $S$, Wongsasuluk $P$, Siriwong W, Borjan $M$, Robson $M$ (2014) Non-carcinogenic hazard maps of heavy metal contamination in shallow groundwater for adult and aging populations at an agricultural area in northeastern Thailand. Hum Ecol Risk Assess 20(3):1546-1560. https://doi.org/10.1007/s1065 3-013-9537-8

11. Dan OF, Aho ED, Ahouansou MM, Sintondji LO, Assoti L, Zandagba J, Amouzouvi D (2018) Study of the physico-chemical and bacteriological characteristics of drinking water in SoAva, South Benin. J Water Res Prot 10:1031-1046. https://doi. org/10.4236/jwarp.2018.1011060

12. Djaouda $M$, Njiné $T$, Liang $S$, Menye $D E$, Gaké $B$, Togouet $S H Z$, Nola M (2014) Bacteriological quality of well waters in Garoua, North Cameroon. Water Qual Expo Health 6:161-176. https:// doi.org/10.1007/s12403-014-0120-z

13. Douagui AG (2013) Risques de pollution de la nappe du Quaternaire de la zone sud du District d'Abidjan: cas du secteur Canal de Vridi-Grand-Bassam (Côte d'Ivoire). Thèse unique. Université Nangui Abrogoua

14. Douagui AG, Kouamé KI, Koffi K, Dibi B, Konan KF, Savané I (2009) Origines et modélisation de la minéralisation des eaux du Quaternaire d'Abidjan (Sud de la Côte d'Ivoire). Biol Chem Sci 5:856-869. https://doi.org/10.4314/ijbcs.v3i5.51049

15. Dovonou EF, Alassane A, Adjahossou NV, Agbodo B, Djibril R, Mama D (2017) Impacts de l'assainissement autonome sur la qualité des eaux de puits dans la Commune de Sèmè-Podji (SudBénin). Int J Biol Chem Sci 6:3086-3099

16. Egbueri JC, Mgbenu CN (2020) Chemometric analysis for pollution source identification and human health risk assessment of water resources in Ojoto Province, southeast Nigeria. Appl Water Sci 10:98. https://doi.org/10.1007/s13201-020-01180-9

17. Elisante E, Muzuka ANN (2016) Assessment of sources and transformation of nitrate in groundwater on the slopes of Mount Meru, Tanzania. Environ Earth Sci 75(3):1-15. https:// doi.org/10.1007/s12665-015-5015-1

18. Fabro AYR, Ávila JGP, Alberich MVE, Sansores SAC, CamargoValero MA (2015) Spatial distribution of nitrate health risk associated with groundwater use as drinking water in Merida, Mexico. Appl Geogr 65:49-57. https://doi.org/10.1016/j.apgeo g.2015.10.004

19. Fallahzadeh RA, Ghaneian MT, Miri M, Dashti MM (2017) Spatial analysis and health risk assessment of heavy metals concentration in drinking water resources. Environ Sci Pollut Res. https:// doi.org/10.1007/s11356-017-0102-3

20. Gao Y, Yu G, Luo C, Zhou P (2012) Groundwater nitrogen pollution and assessment of its health risks: a case study of a typical village in rural-urban continuum, China. PLoS ONE 7(4):e33982. https://doi.org/10.1371/journal.pone.0033982

21. Grzybowski M, Lenczewsk ME, Yee Oo Y (2019) Water quality and physical hydrogeology of the Amarapura township, Mandalay, Myanmar. Hydrogeol J 27:1497-1513. https://doi.org/10.1007/ s10040-018-01922-9

22. Hassane A, Leduc C, Favreau G, Bekins B, Margueron T (2016) Impacts of a large Sahelian city on ground water hydrodynamics and quality: example of Niamey (Niger). Hydrogeol J 2:407-423. https://doi.org/10.1007/s10040-015-1345-z

23. He X, Li P, Wu J, Wei M, Ren X, Wang D (2020) Poor groundwater quality and high potential health risks in the Datong Basin, northern China: research from published data. Environ Geochem Health. https://doi.org/10.1007/s10653-020-00520-7

24. Hounsounou E, Agassounon DTM, Kelomè NC, Vissin EW, Mensah GA, Agbossou E (2016) Domestic water pollution in deprived urban areas in developing countries: literature review. Int J Biol Chem Sci 10(5):2392-2412

25. Inza B, Yao KJ (2015) Physical and chemical parameters and trace metal concentrations in the Ebrie Lagoon (Côte d'Ivoire). J Mater Environ Sci 5:1321-1329

26. Issiaka S, Albert GB, Aristide DG, Innocent KK, Xu Y, Usher B (2006) Vulnerability assessment of Abidjan quaternary aquifer using the DRASTIC method. In: Xu Y, Usher B (eds) Groundwater pollution in Africa. Taylor \& Francis/Balkema, Leiden, pp 115-124

27. Kouame KI (2007) Pollution physico-chimique des eaux dans la zone de la décharge d'Akouédo et analyse du risque de contamination de la nappe d'Abidjan par un modèle de simulation des écoulements et du transport des polluants. Thèse de Doctorat, Université d'Abobo-Adjamé, Abidjan

28. Kouamenan NM, Coulibaly S, Atse BC, Goore BG (2019) Seasonal and spatial variations of heavy metals in water and sediments from mainland and maritime areas of Ebrie lagoon (Côte d'Ivoire, Western Africa). Int J Biol Chem Sci 13(4):2374-2387

29. Tuo AD, Soro MB, Trokourey A, Bokra Y (2015) Evidence of Organic Pollution Observed in Ebrié Lagoon around Abidjan 
City (Côte d'Ivoire). Am Int J Res Form Appl Nat Sci 40-45. ISSN (Online): 2328-3785

30. Kanoti JR, Olago D, Opiyo N, Nyamai C, Dulo S, Ayah R (2019) Microbial and physical chemical indicators of groundwater contamination in Kenya: a case study of Kisumu Aquifer System, Kenya. J Water Res Prot 11:404-418. https://doi.org/10.4236/ jwarp.2019.114024

31. Kapembo ML, Laffite $A$, Bokolo $M K$, Mbanga AL, Maya-Vangua MM, Otamonga J-P, Mulaji CK, Mpiana PT, Wildi W, Pote J (2016) Evaluation of water quality from suburban shallow wells under tropical conditions according to the seasonal variation, Bumbu, Kinshasa, Democratic Republic of the Congo. Expo Health 8:487-496. https://doi.org/10.1007/s12403-016-0213-y

32. Kate $S$, Kumbhar $S$, Jamale $P(2020)$ Water quality analysis of Urun-Islampur City, Maharashtra, India. Appl Water Sci 10:95. https://doi.org/10.1007/s13201-020-1178-3

33. Ketchemen-Tandia B, Boum-Nkot SN, Ebondji SR, Nlend BY, Emvoutou H, Nzegue O (2017) Factors influencing the shallow groundwater quality in four districts with different characteristics in urban area (Douala, Cameroon). J Geosc Env Protect 5:99-120. https://doi.org/10.4236/gep.2017.58010

34. Kfle G, Sium M, Manohar A, Debretsion S, Tesfamariam A, Tesfalem N, Okbaselasie A, Tesfay K (2019) Investigation of the physico-chemical standards of the ground waters around MaiBella Area in Asmara. J Geosc Env Protect 7:148-161. https://doi. org/10.4236/gep.2019.79011

35. Konan KF, Leprieur F, Ouattara A, Brosse S, Grenouillet G, Gourène $G$, Winterton $P$, Lek $S$ (2006) Spatio-temporal patterns of fish assemblages in coastal West African rivers: a self-organizing map approach. Aquat Living Resour 19:361-370. https:// doi.org/10.1051/alr:2007006

36. Kumar A, Kumar A, Cabral-Pinto MMS, Chaturvedi AK, Shabnam AA, Subrahmanyam G, Mondal R, Gupta DK, Malyan SK, Kumar SS, Khan SA, Yadav KK (2020) Lead toxicity: health hazards, influence on food chain, and sustainable remediation approaches. Int J Environ Res Public Health 17:2179. https://doi.org/10.3390/ ijerph17072179

37. Lagnika M, Ibikounle M, Montcho J-PC, Wotto VD, Sakiti NG (2014) Physico-chemical characteristics of well water in the commune of Pobè (Benin, West Africa). J Appl Biosci 79:68876897. https://doi.org/10.4314/jab.v79i1.13

38. Lapworth DJ, Krishan G, MacDonald AM, Rao MS (2017) Groundwater quality in the alluvial aquifer system of northwest India: new evidence of the extent of anthropogenic and geogenic contamination. Sci Total Environ 599-600:1433-1444. https:// doi.org/10.1016/j.scitotenv.2017.04.223

39. Li P, Wu J, Qian H (2016) Regulation of secondary soil salinization in semi-arid regions: a simulation research in the Nanshantaizi area along the Silk Road, northwest China. Environ Earth Sci 75(8):698

40. Liu CW, Lin KH, Kuo YM (2003) Application of factor analysis in the assessment of groundwater quality in a blackfoot disease area in Taiwan. Sci Total Environ 313(1-3):77-89

41. Loroux $B$ (1978) Contribution à l'étude hydrogéologique du bassin sédimentaire de Côte d'Ivoire. Thèse de Doctorat, Université de Bordeau I

42. Lukubye B, Andama M (2017) Physico-chemical quality of selected drinking water sources in Mbarara Municipality, Uganda. J Water Res Prot 9:707-722. https://doi.org/10.4236/ jwarp.2017.97047

43. Ministère de la santé et de l'hygiène publique de Côte d'Ivoire (2018) Rapport annuel sur la situation sanitaire, Direction de l'informatique et de l'information sanitaire, Côte d'Ivoire, $407 \mathrm{p}$. http://dipe.info/index.php/fr/component/jdownloads/send/6rapport-annuel-sur-la-situation-sanitaire/61-rass-2018-vf?Itemi $\mathrm{d}=0$. visité le 23 Mars 2020
44. Ministère de la santé et de l'hygiène publique de Côte d'Ivoire (2017) Rapport annuel sur la situation sanitaire, Direction de l'informatique et de l'information sanitaire, Côte d'Ivoire, $397 \mathrm{p}$. http://dipe.info/index.php/fr/component/jdownloads/send/6rapport-annuel-sur-la-situationsanitaire/55-rapport-annue I-sue-la-situation-sanitaire-rass-version-2017? |temid=0. Visited on March 23, 2020

45. Ministère de la santé et de l'hygiène publique de Côte d'Ivoire (2016) Rapport annuel sur la situation sanitaire, Direction de l'informatique et de l'information sanitaire, Côte d'Ivoire, 397 p. http://dipe.info/index.php/fr/component/jdownloads/send/6rapport-annuel-sur-la-situation-sanitaire/52-rapport-annue |-sur-la-situation-sanitaire-rass?|temid=0. Visited on March 23, 2020

46. Mishra S, Kumar A (2020) Estimation of physicochemical characteristics and associated metal contamination risk in the Narmada River, India. Environ Eng Res 26(1):190521

47. Njueya KA, Likeng HDJ, Nono A (2012) Hydrodynamique et qualité des eaux souterraines dans le bassin sédimentaire de Douala (Cameroun): cas des aquifères sur formations Quaternaires et Tertiaires. Int J Biol Chem Sci 6(4):1874-1894

48. Park YS, Cereghino R, Compin A, Lek S (2003) Applications of artificial neural networks for patterning and predicting aquatic insect species richness in running waters. Ecol Model 160:265280. https://doi.org/10.1016/S0304-3800(02)00258-2

49. Rao MS, Krishan G, Kumar CP, Purushothaman P, Kumar S (2017) Observing changes in groundwater resource using hydrochemical and isotopic parameters: a case study from Bist Doab, Punjab. Environ Earth Sci 76:175. https://doi.org/10.1007/s1266 5-017-6492-1

50. Recensement Général de la Population et de l'Habitat de Côte d'Ivoire (2014) Résultats globaux. http://www.ins.ci/n/RESUL TATS\%20GLOBAUX.pdf. Visited 18 May 2020

51. Sanchez-Perez JM, Tremolieres M (2003) Change in groundwater chemistry as a consequence of suppression of floods: the case of the Rhine floodplain. J Hydrol 270:89-104. https://doi. org/10.1016/S0022-1694(02)00293-7

52. Soro G (2010) Quantitative and qualitative assessment of groundwater resources in the Lakes Region (Central Côte d'Ivoire): hydrogeology and hydrochemistry of discontinuous aquifers in Yamoussoukro District and Tiébissou Department. Thesis of Cocody University, Abidjan, Côte d'Ivoire, p 250

53. Soro TD, Soro G, Ahoussi KE, Oga YMS, Soro N (2019) Hydrogeochemical and groundwater quality studies in the High Bandama Watershed at Tortiya (Northern of Côte d'Ivoire). J Geosci Environ Protect 7:49-61. https://doi.org/10.4236/gep.2019.72004

54. Su H, Kang W, Xu Y, Wang J (2018) Assessing groundwater quality and health risks of nitrogen pollution in the Shenfu mining area of Shaanxi Province, northwest China. Expo Health 10:77-97. https://doi.org/10.1007/s12665-017-6781-8

55. Tandia A, Diop E, Gaye C (1999) Nitrate pollution of the phreatic aquifers under an unsanitized semi-urban environment: example of the Yeumbeul aquifer, Senegal. J Afr Earth Sci 29(4):809-822

56. WHO (2011) Guidelines for drinking-water quality, 4th edn. 594 $\mathrm{p}$

57. Wongsasuluk $P$, Chotpantarat S, Siriwong W, Robson M (2014) Heavy metal contamination and human health risk assessment in drinking water from shallow groundwater wells in an agricultural area in Ubon Ratchathani province, Thailand. Environ Geochem Health 36(1):169-182

58. Wu J, Sun Z (2016) Evaluation of shallow groundwater contamination and associated human health risk in an alluvial plain impacted by agricultural and industrial activities, mid-west China. Expo Health 8:311-329 
59. Wu J, Li P, Qian H (2015) Hydrochemical characterization of drinking groundwater with special reference to fluoride in an arid area of China and the control of aquifer leakage on its concentrations. Environ Earth Sci 73(12):8575-8588. https://doi. org/10.1007/s12665-015-4018-2

60. Yapo OB, Mambo V, Seka A, Ohou A, Konan F, Gouzilé V, Tidou A, Kouamé $V$, Houenou $P$ (2010) Evaluation de la qualité des eaux de puits à usage domestique dans les quartiers défavorisés de quatre communes d'Abidjan (Côte d'Ivoire): Koumassi, Marcory, Port-Bouet et Treichville. Int J Biol Chem Sci 2:289-307. https:// doi.org/10.4314/ijbcs.v4i2.58111
61. Yapo RI, Mambo V, Alder AC, Ohou-Yao MJ, Ligban R, Dao D, Stamm C, Bonfoh B (2016) Seasonal characterization of well water for vegetables and domestic use in Korhogo (Côte d'Ivoire). Int J Biol Chem Sci 10:15. https://doi.org/10.4314/ijbcs .v10i3.41

Publisher's Note Springer Nature remains neutral with regard to jurisdictional claims in published maps and institutional affiliations. 